\title{
Preoperative Evaluation of Craniopagus Twins: Anatomy, Imaging Techniques, and Surgical Management
}

\author{
(D) A.E. Goldman-Yassen, (D).T. Goodrich, (D)T.S. Miller, and (D).M. Farinhas
}

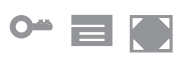

\begin{abstract}
SUMMARY: Craniopagus twins are a rare congenital malformation in which twins are conjoined at the head. Although there is high prenatal and postnatal mortality for craniopagus twins, successful separation has become more common due to advances in neuroimaging, neuroanesthesia, and neurosurgical techniques. Joined brain tissue, shared arteries and veins, and defects in the skull and dura make surgery technically challenging, and neuroimaging plays an important role in preoperative planning. Drawing on our experience from consultation for multiple successful separations of craniopagus twins, we discuss what radiologists need to know about the anatomy, classification, imaging techniques, and surgical management of craniopagus twins.
\end{abstract}

ABBREVIATIONS: $\mathrm{CPT}=$ craniopagus twins; $\mathrm{CVS}=$ circumferential venous sinus; SDVS $=$ shared dural venous sinuses; $\mathrm{TA}=$ total angular; TV $=$ total vertical

C raniopagus twins $(\mathrm{CPT})$ are a rare congenital malformation in which twins are conjoined at the head. It accounts for only $2 \%-6 \%$ of conjoined twins, with an incidence of approximately 1 in 2.5 million lives births. ${ }^{1,2}$ The skulls are most often joined at homologous regions on each twin in both vertical and angular orientations, with the face and foramen magnum not primarily involved. ${ }^{3}$ CPT can manifest as total, the twins share dural venous sinuses (SDVS), and partial forms, with separate venous anatomy. ${ }^{4}$ Although there is high prenatal and postnatal mortality for CPT, successful separation has become more common due to advances in neuroimaging, neuroanesthesia, and neurosurgical techniques. ${ }^{4-20}$ Joined brain tissue, shared arteries and veins, and defects in the skull and dura make surgery technically challenging. ${ }^{21}$ Separation can take place in single or multistage procedures

Received November 6, 2019; accepted after revision February 10, 2020.

From the Department of Radiology (A.E.G.-Y.), Children's Hospital of Philadelphia, Philadelphia, Pennsylvania; Departments of Radiology (A.E.G.-Y., J.M.F.) and Neurosurgery (J.T.G.), Montefiore Medical Center, Bronx, New York; Department of Radiology (T.S.M.), Stamford Hospital, Stamford, Connecticut; and Department of Radiology (J.M.F.), Moffitt Cancer Center Tampa, Florida.

Paper previously presented as an educational exhibit at: Annual Meeting of the Radiological Society of North America, November 25-29, 2018; Chicago, Illinois; presentation NR274-ED-X.

Please address correspondence to Adam Goldman-Yassen, MD, MS, Children's Hospital of Philadelphia, 3401 Civic Center Blvd, Philadelphia, PA 19104; e-mail: adgoldmanyassen@gmail.com; @AdGoldmanYassen

-- Indicates open access to non-subscribers at www.ajnr.org

Indicates article with supplemental on-line table.

Indicates article with supplemental on-line photos.

http://dx.doi.org/10.3174/ajnr.A6571 and has evolved as the understanding of the physiology, surgical techniques, and technology of CPT have improved. ${ }^{16}$

Neuroimaging, including CT, MR imaging, and conventional angiography, plays an important role in mapping the shared arterial and venous structures, brain parenchyma, calvaria, and dura. ${ }^{22-24}$ Understanding the shared vascular anatomy is important for surgical planning because separating common vessels is associated with complications such as thrombosis, air embolism, infarction, and hemorrhage. ${ }^{25}$ Digital and physical 3D models generated from CT and MR imaging data are important tools for operative planning and as a guide in the operating room. ${ }^{21}$ We will review the preoperative radiologic evaluation of $\mathrm{CPT}$, including the anatomy, classification systems, and surgical management, that is important for the radiologist to understand. We draw on our experience in consultation for multiple successful CPT separations with an experienced neurosurgical specialist in CPT.

\section{Embryology}

The monoamniotic, monochorionic type of monozygotic twinning has the greatest potential for leading to conjoined twins. ${ }^{26}$ The 2 main competing theories of how monoamniotic monozygotic twins conjoin are the "fission" and "fusion" theories. ${ }^{27}$ The fission theory suggests incomplete splitting or cleavage of the embryo at the primitive streak stage, leading to conjoined fetuses. This theory explains the apparent increase in the incidence of situs inversus and mirror imaging in conjoined twins, because a dividing cell or cell mass maintains mirror imaging. ${ }^{26}$ The fusion theory suggests that embryos rejoin at vulnerable sites after initial complete 


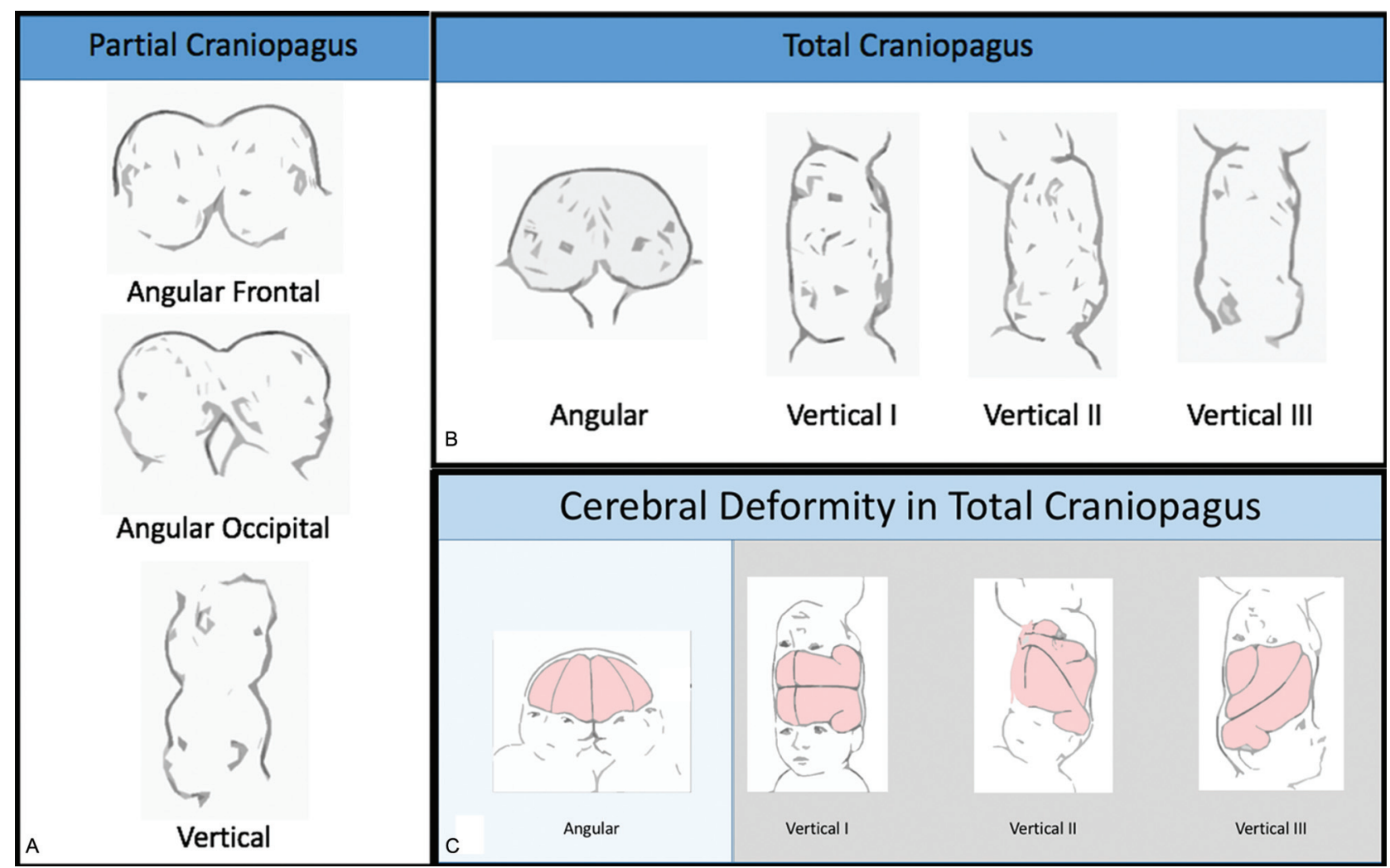

FIG 1. Stone and Goodrich ${ }^{7}$ classification for CPT. Partial CPT lack substantial shared dural venous sinuses. Total CPT share a large portion of dural venous sinuses and present with pronounced brain compression, leading to distortion within the cranium. The 2 main subtypes are based on the long-axis angle between twins: angular and vertical. Shared calvaria causes deformity of each twin's brain. Reproduced with permission from Stone and Goodrich, 2006 . $^{7}$
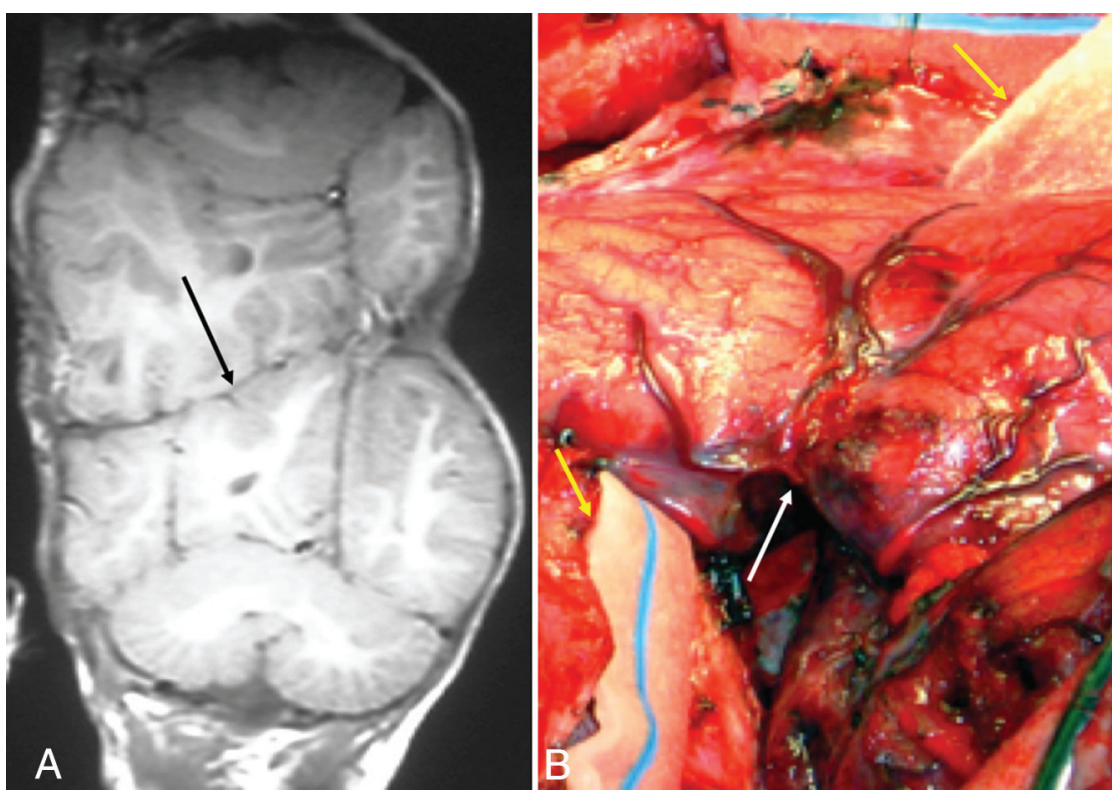

FIG 2. A, T1-weighted MR imaging does not clearly show conjoined brain tissue in this total CPT. However, no clear dura between cerebral hemispheres and interdigitating of gyri (black arrow) is seen. $B$, Intraoperative photograph from the same patient demonstrating conjoined brain tissue (white arrow) along the axis defined by the flanking neurosurgical sponges (yellow arrows). separation. This theory accounts for the various angles at which conjoined twins can be fused, along either the dorsal-ventral axis or rostro-caudal axis. $^{27}$ The extent to which the twins are conjoined and the time of fusion during development will determine how the anatomic structures will adapt.

\section{Classification Systems}

Multiple classification systems have been proposed for CPT (On-line Table). ${ }^{3,4,21,25,28}$ The first was developed by O'Connell, ${ }^{29}$ in which CPT were classified as partial or total; total CPT share an extensive surface area with widely connected cranial cavities, while in partial CPT, only a limited, superficial surface area is affected. He subdivided partial craniopagus twins on the basis of the degree of rotation of one head in relation to the other, with different deformities of the brain and abnormal circulation for each. Type I vertical CPT face the same direction, type II CPT face 


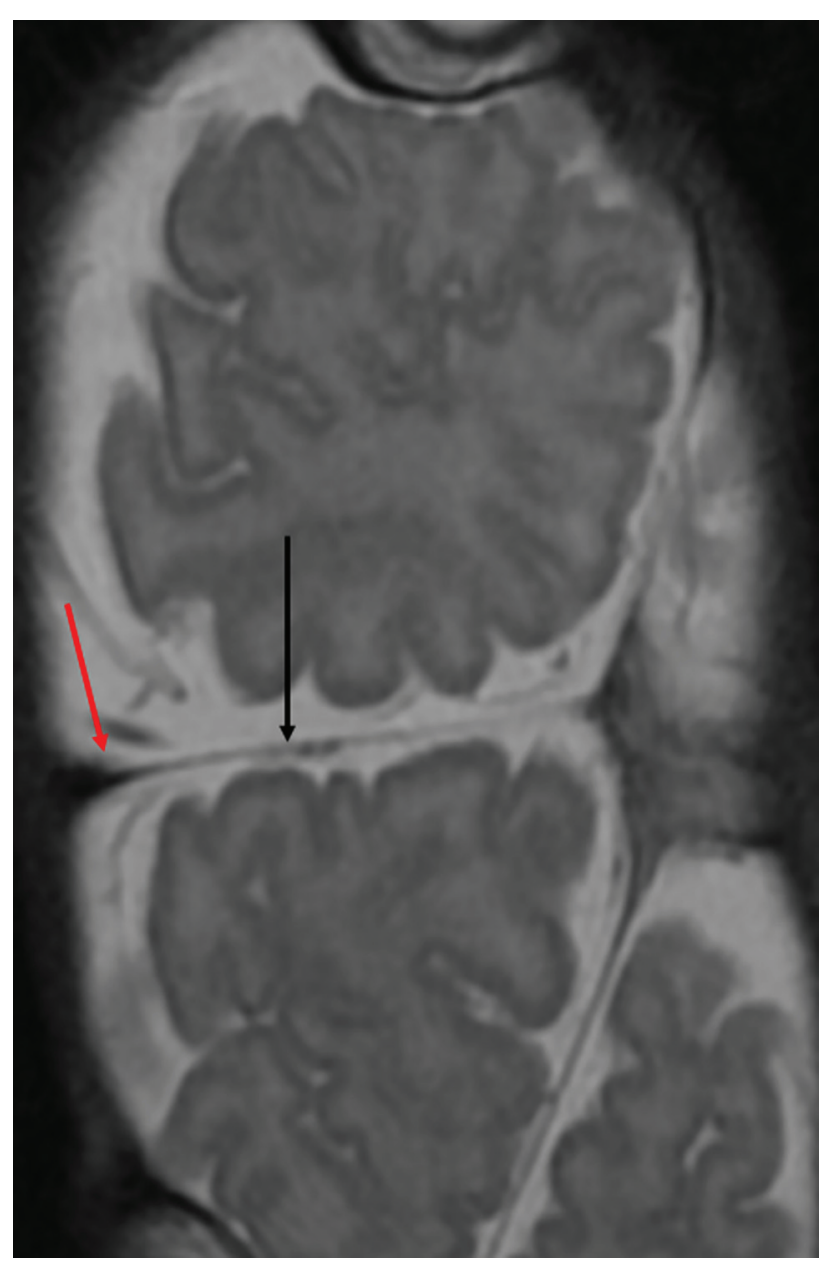

FIG 3. Coronal T2-weighted image demonstrates cerebral tissue separated by a single-layer transverse dural septum (black arrow). The CVS courses in the periphery of the septum (red arrow).

opposite sides, and type III twins have an intermediate angle of rotation.

On the basis of review of 64 cases, Stone and Goodrich ${ }^{7}$ defined partial CPT as lacking substantial shared dural venous sinuses, whereas total CPT share a large portion of their dural venous sinuses and present with pronounced brain compression, which leads to distortion within the cranium. They defined 2 main subtypes based on the long-axis angle between twins: angular and vertical (Fig 1). Vertical craniopagus calvaria is continuous and is further subdivided on the basis of intertwin axial facial rotation, similar to the O'Connell classification. Because the Stone and Goodrich classification is most commonly used, we will use it for discussion of CPT anatomy.

\section{Anatomy}

CPT are attached only at the calvaria, without involvement of the foramen magnum, skull base, vertebrae, or face. ${ }^{30}$ Other conjoined twinning variations involving the head include cephalopagus (involving the brain, face, thorax, and upper abdomen), parapagus diprosopus ( 2 faces on 1 head with 1 body), and rachipagus (joined dorsally along the vertebra and occasionally along the occiput). Conjunction is rarely symmetric and may involve any portion of the head, including underlying structures such as meninges, venous sinuses, or cortex. Configuration can vary on the basis of the attachment location and degree of rotation and angulation between the 2 twins, which will define the anatomy and difficulty of separation.

\section{Partial CPT}

Cranial unions in partial CPT are usually frontal and, less commonly, occipital or vertical biparietal. ${ }^{11,17,31-40}$ The junctional diameter is often smaller in the partial CPT than in other types of $\mathrm{CPT}$, and an incomplete layer of bone may be present between the twins. ${ }^{17,34,38}$ In partial CPT, each child largely maintains independent calvarial convexities, except at the common area of skull junction. Cerebral deformities and compaction tend to be local and mild. The dura of each twin may be intact or deficient, and the cortical gyri may interdigitate. If the gyri do interdigitate, surgical separation is much more complex (Fig 2). Although the leptomeninges can sometimes be separable, when there is associated leptomeningeal vessel cross-over, the subsequent division will lead to some postoperative morbidity. ${ }^{31,40}$ Dural venous cross-circulation (SDVS) is absent or negligible. Children with partial CPT undergo successful separation at an earlier age than those with total CPT, and the separation more often results in survival of both children without severe disability. ${ }^{7}$

\section{Total Vertical CPT}

The total vertical (TV) type of CPT consists of a longitudinal arrangement with the general appearance of 1 common continuous cranium housing 4 cerebral hemispheres. ${ }^{4,29}$ Minor longitudinal tilting, "stove-piping," between the twins is common with a longitudinal intertwin axis or angle of $140^{\circ}-180^{\circ} .{ }^{29}$ An incomplete or complete, single-layered transverse dural septum typically separates the cerebral hemispheres deep to the conjoined region (Fig 3). The falx cerebri is usually absent or anomalous. The major cerebral arterial supply is usually confined to each respective twin. On occasion, in addition to small interconnecting leptomeningeal vessels, conjoined brain tissue may contain a larger artery requiring division at surgery. ${ }^{9,41}$ There have been some reported cases of shared cerebral arterial supply, such as the shared middle cerebral artery circulation, which increases the complexity of a separation and may preclude safe separation., ${ }^{8,42}$

There are a variety of cerebral venous abnormalities associated with total CPT. Because total CPT lack 2 complete dural envelopes, the peripheral dural shelf at the conjoined cerebral hemispheric zone encloses a circumferential venous sinus (CVS) (Fig 4). ${ }^{29,43-45}$ In TV CPT, the CVS generally traverses at least the hemicircumference of the conjoined region and replaces the absent superior sagittal sinus of both twins. ${ }^{4,29}$ The CVS assumes an increasingly oblique configuration with increasing interaxial rotation between the TV CPT, conforming to the lateral hemispheric cleavage plane. The CVS drains the homolateral superior cerebral hemispheres of each twin, empties into a common or asymmetrically shared posterior confluence of sinuses, and may connect the lateral sinus of one twin to the lateral sinus of the other. Other types of shared venous drainage include venous sinus "lakes," a single shared superior sagittal sinus, or separate superior sagittal sinuses with variable interconnections between them. ${ }^{24,29,46}$ The nature of the cerebral venous 

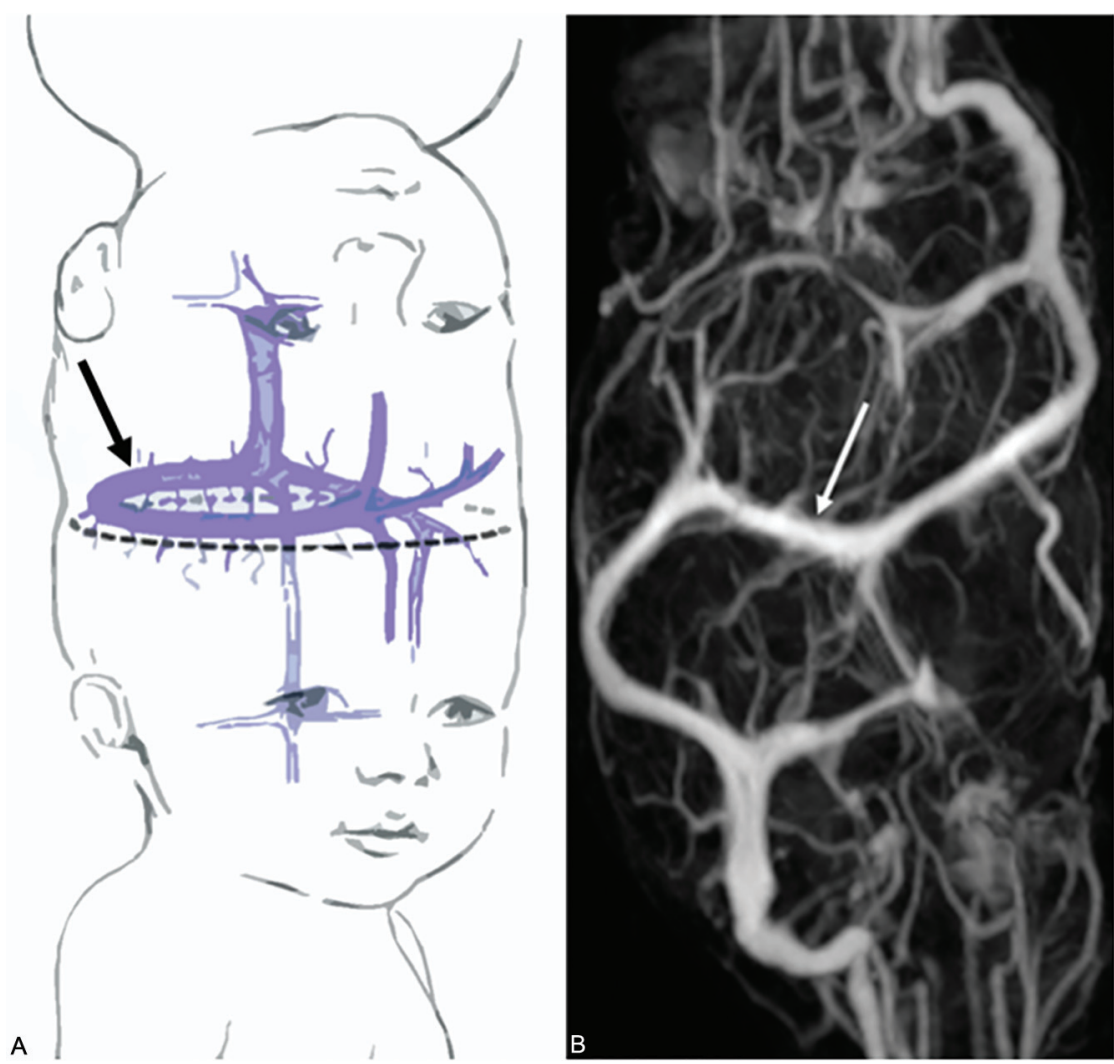

FIG 4. A, Surgical-separation strategy may entail sequential division of venous sinus branches from the nondominant twin (dashed line), allowing the anatomically predisposed dominant twin to keep the CVS (black arrow) and associated dura. In the nondominant twin, subsequent reversal of venous drainage to collateral basal channels may be induced (Reproduced, with permission, from Stone and Goodrich, ${ }^{7}$ 2006). B, Postcontrast MR venography demonstrates the CVS (white arrow).

system is an important prognostic indicator of successful separation because complications during separation can lead to substantial blood loss and a catastrophic result for 1 or both children. ${ }^{7}$ Both the CVS and SDVS are always present in TV forms of CPT, making successful surgical separation particularly hazardous.

The cerebral hemispheres in TV type I CPT demonstrate relatively symmetric superior biparietal or vertex compressive flattening. The anterior and middle fossae are spacious, while the posterior fossa tends to be small. ${ }^{47}$ Slight tilting or intertwin axial rotation leads to facial asymmetry. Later, positional plagiocephaly is common because intertwin orientation is fixed and individual twin movement is limited by the weight and positioning of the other twin. Progressive axial rotation between the twins during development in TV types II and III produces a progressively marked obliquity of the conjoined junction. This results in oblique cerebral hemispheric compression and craniofacial and middle and posterior fossa deformities. ${ }^{29}$ The marked bone, dural, and cerebral asymmetries in TV types II and III CPT compound the difficulties of surgical separation. ${ }^{7}$ In addition to compressed cerebral tissue in TV CPT (Fig 1C), a fused cerebral cortex and underlying white mater are also found. ${ }^{9,29,47}$

\section{Total Angular CPT}

Total angular (TA) CPT have more acute intertwin longitudinal angulation and SDVS accompanied by complex, interconnecting venous channels (or CVS) and markedly distorted cerebral hemispheres. ${ }^{48-52}$ One twin's brain can be inside the other twin's calvaria, adding additional to the complexity of the surgical separation. Cerebral compaction, distortion, and displacement may result in skull base deformity. Most of the TA forms of CPT are joined asymmetrically with intertwin axial rotation, but some are roughly symmetric. ${ }^{10,52-55}$ TA CPT have shown greater extent of conjoined brain tissue, including the cerebellum, and cerebral arterial cross-filling than TV CPT (Fig 5 and On-line Fig 1). ${ }^{3,25,49,55,56}$ TA twins are, therefore, more challenging to separate.

\section{Anatomic Comorbidities.}

CPT often present with additional comorbidities, including cardiovascular, genitourinary, craniofacial, and neurologic abnormalities. ${ }^{46}$ Specific comorbidities include patent ductus arteriosus, aortic coarctation, hypertension, hypotension, genitourinary dysfunction and aplasia, hemiparesis, cleft lip and palate, anorectal agenesis, sirenomelia, and developmental delay. The presence of additional comorbidities increases the risk of surgery, and they are important considerations before operative management is decided. Imaging plays a key role in delineating all anatomic abnormalities present in each twin. TA CPT have a higher rate of comorbidities than TV twins, most notably genitourinary anomalies. $^{46}$

\section{Sedation Considerations}

CT and occasionally MR imaging can be performed in neonates with a mere "feed and wrap" approach without sedation. ${ }^{57}$ Older infants usually require general anesthesia for CT and MR imaging. Neuroanesthesia involvement is essential, using a dedicated team of anesthesiologists and equipment for each child, with closed-loop communication between teams to avoid confusion and drug errors and strict labeling of the twins to avoid confusion between them while dosing medications. ${ }^{58,59}$ Pharmacokinetics and pharmacodynamics in CPT are altered due to circulatory mixing, and medications administered to one twin may have unexpected effects on the other. ${ }^{60}$ Mask ventilation, access to airway, and intubation are also difficult due to the angle between the heads. ${ }^{61}$ During imaging, it is ideal to position the twins in the position planned for surgery. This helps the surgeons become oriented to the structures as they would appear on the table during surgery. ${ }^{20}$

\section{Imaging Modalities}

Prenatal Imaging. Prenatal sonography (Fig 6A) and fetal MR imaging can be used to identify CPT in utero. The lack of 


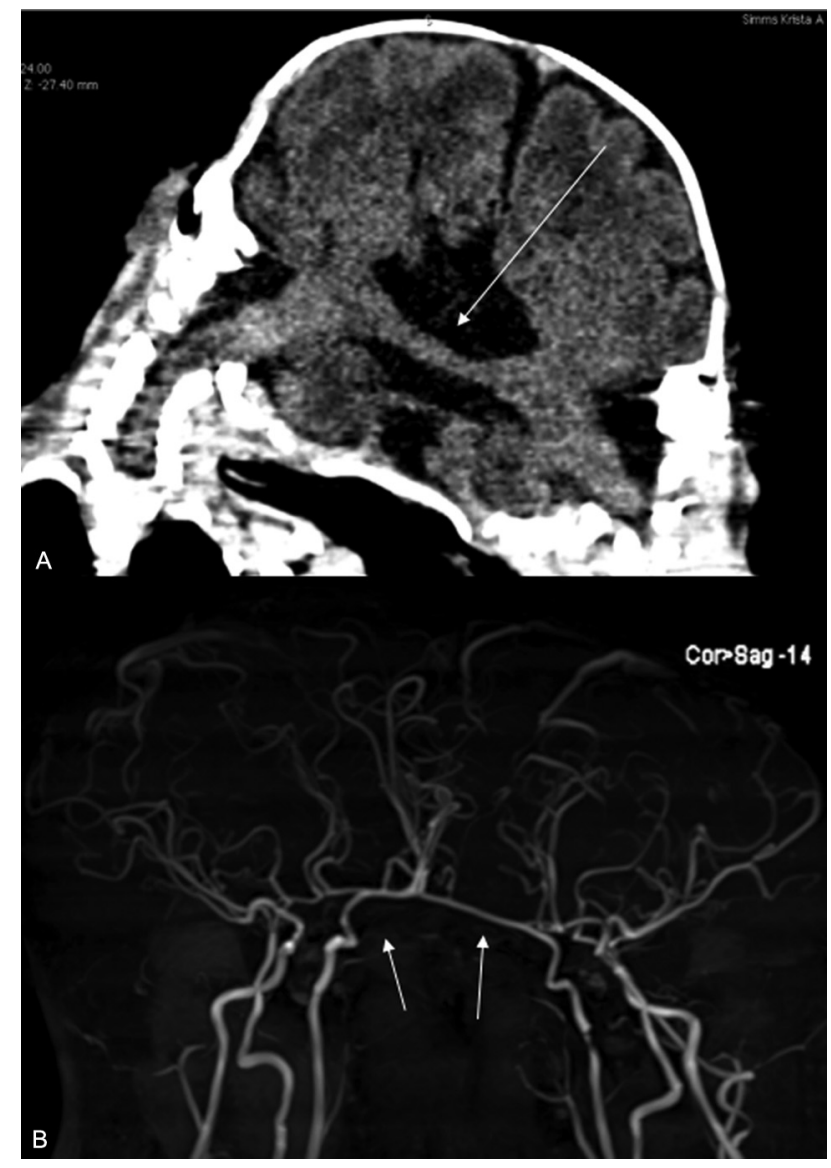

FIG 5. Coronal CT $(A)$ of TA CPT shows shared brain parenchyma, including a diencephalic bridge (arrow). MRA of the brain (B) from the same patients demonstrates a shared MCA (arrows), with an appearance similar to that of the anterior cerebral artery. This set of twins cannot be separated.

ionizing radiation in both modalities makes them ideal for prenatal imaging. Antenatal diagnosis of conjoined twins can be made with ultrasonography as early as 12 weeks' gestation and is important for optimal obstetric management. ${ }^{62}$ Prenatal diagnosis may be suspected and confirmed if 2 fetuses cannot be visualized separately in a single gestational sac. A bifid appearance of the first trimester fetal pole, presence of $>3$ umbilical cord vessels, persistence of heads at the same level and body plane, and failure of the fetuses to change position relative to each other with time are other sonographic features that assist in making the diagnosis. ${ }^{63} 3 \mathrm{D}$ sonography may be more accurate than $2 \mathrm{D}$ sonography alone for defining the extent of the shared calvarial area and direction of the faces. ${ }^{64}$

Fetal MR imaging allows superior assessment of intracranial structures, including the fetal brain, vasculature, and other softtissue structures, and is routinely used to evaluate CPT prenatally (Fig 6B). ${ }^{65}$ Fast imaging techniques are used to image the rapidly moving fetal brain for structural detail, hemorrhage, and diffusion restriction, such as HASTE (Single-shot Fast Spin Echo), EPI, true fast imaging with steady-state precession, and DWI. ${ }^{66}$

CT. High-resolution CT of the head with thin-section images using current pediatric, radiation dose-minimizing protocols is
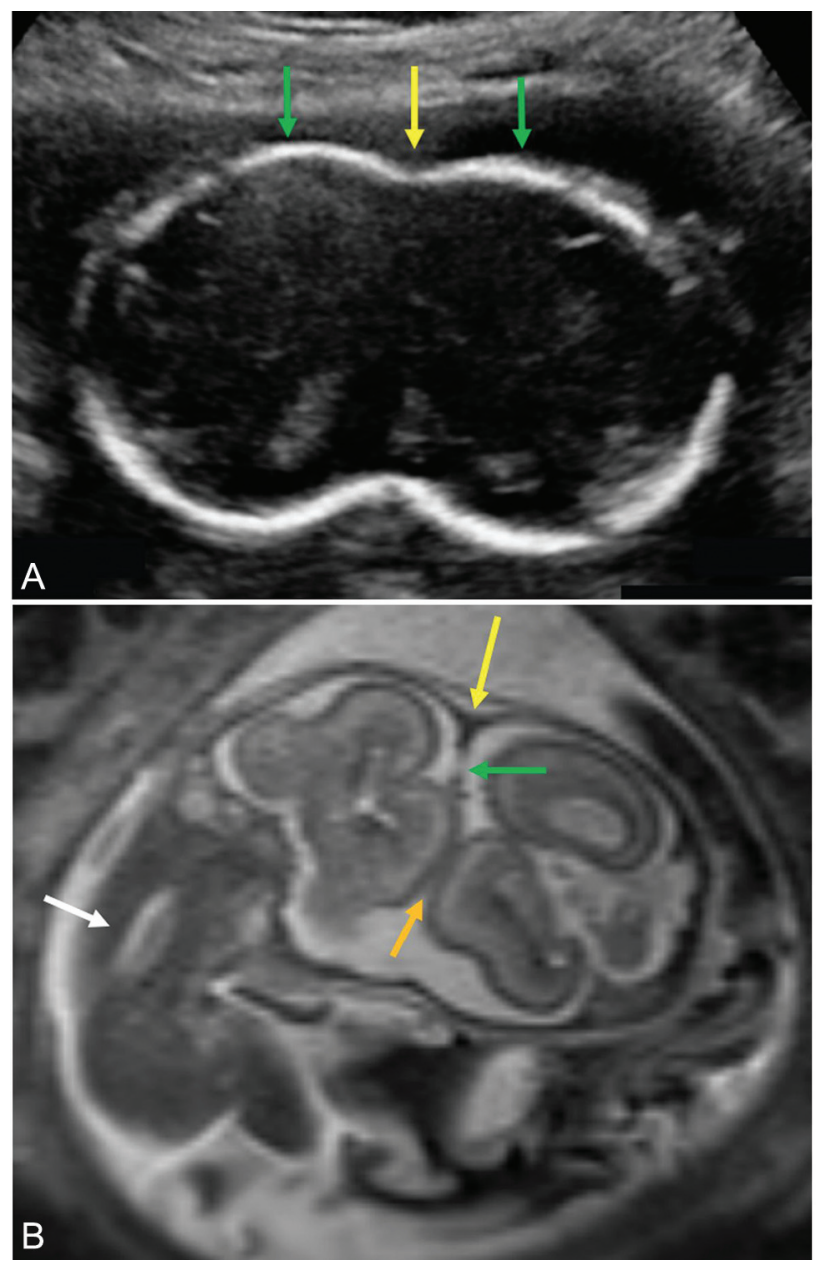

FIG 6. $A, 2 D$ sonogram obtained in the axial plane through the skull of the fetal CPT shows the hyperechoic joined calvaria (green arrows). The point of skull union between the twins is also clearly seen (yellow arrow). B, Fetal MR imaging in the coronal oblique plane through both brains of the CPT. The CVS is seen along the lateral margin of the inner calvaria at the point of bony union (yellow arrow), with the associated dural shelf separating the brains (green arrow). It is likely that the brain is fused where brain surfaces touch, and no dural or CSF cleft is seen (orange arrow). The torso and spine of 1 twin is also seen in this plane (white arrow).

preferred. 3D reconstruction of the CT data is helpful to evaluate the extent of bone fusion (Fig 7A). ${ }^{8}$ These data can then be reconstructed into a $3 \mathrm{D}$ model, which can be used by the surgeon and radiologist in preoperative planning and intraoperative reference. ${ }^{42} \mathrm{CT}$ angiography and venography provide adequate information related to vascularity in the conjoined area (Fig $7 B,-7 C$ ), with CT venography of paramount importance in presurgical planning before each stage of separation. Thin-section, axial raw data can be segmented for vein modeling (On-line Fig 2). The resolution of CT for the evaluation of vessels is superior to contrast-enhanced MR imaging. In most cases of CPT, after the initial presentation, CTA has excluded shared arterial vessels; stage 2 and later CT scans can be protocolled as CT venograms to follow venous redistribution and evaluate veins for separation.

MR Imaging. Brain MR imaging gives a detailed assessment of the brain anatomy and development, including the shared cortex, 


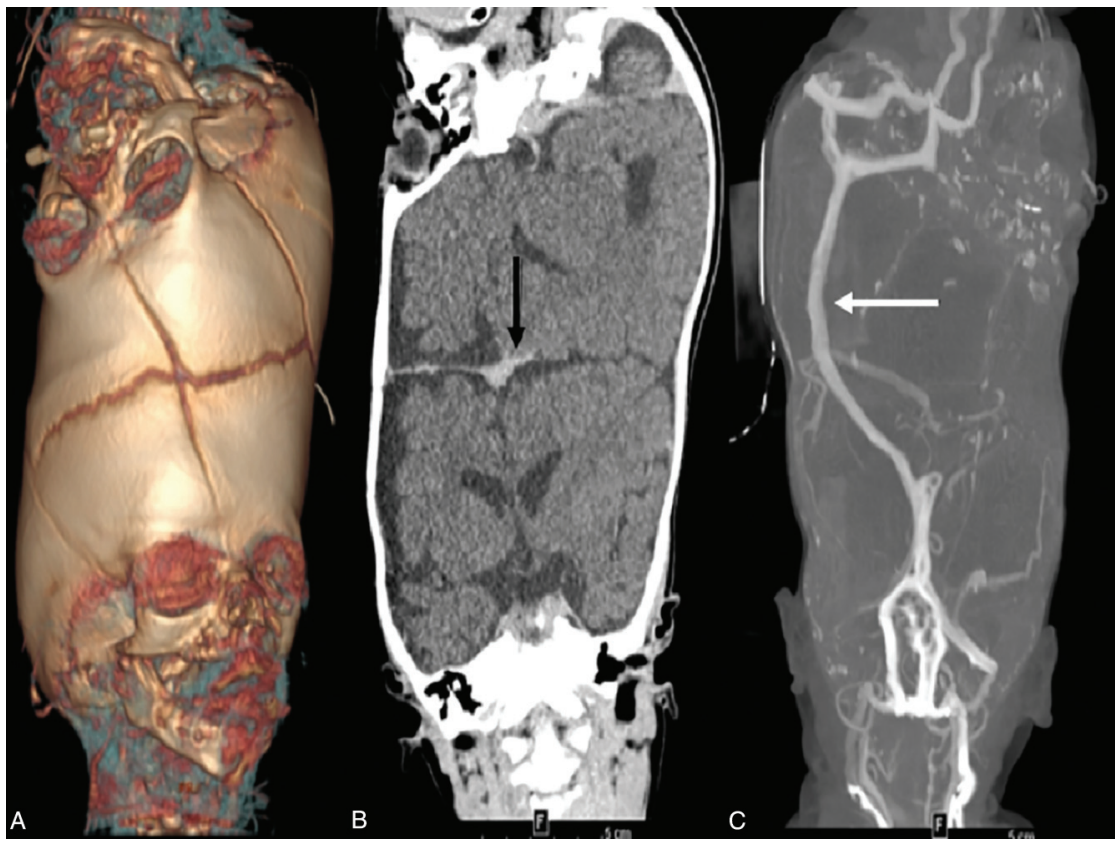

FIG 7. $3 D$ surface rendering from $C T(A)$ demonstrates suture patterns in the fused calvaria. $A$ coronal contrast-enhanced CT venogram $(B)$ demonstrates the orientation of the cerebral hemispheres and the presence of a dural septum (arrow). Maximum intensity projection of a CT venogram (C) demonstrates a shared superior sagittal sinus (arrow).

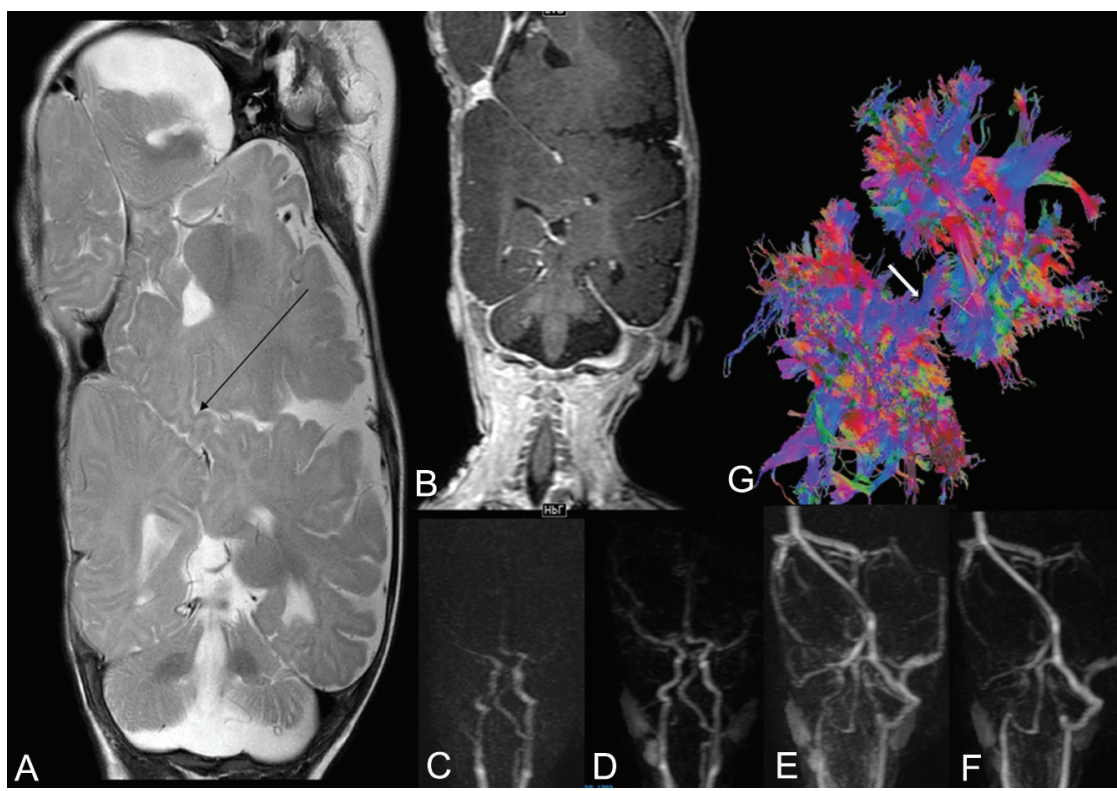

FIG 8. T2-weighted coronal image $(A)$ is concerning for parenchymal bridging between the parietal lobes (arrow). Coronal postcontrast enhanced Tl-weighted image $(B)$ and dynamic MR angiography and venography $(C-F)$ demonstrate a circumferential sinus communicating with both superior sagittal sinuses and dominant occipital sinuses without evidence of arterial anastomosis. Tractography $(G)$ can demonstrate contiguity of white matter tracts in the cephalocaudal direction depicted in blue (arrow).

venous sinuses, ventricular system, dural anatomic details, and other associated anomalies (Fig 8).,42 MR angiography and venography can give detailed assessment of the vascular system, especially in shared areas. Time-resolved MRA (time-resolved imaging of contrast kinetics and timeresolved imaging with stochastic trajectories) helps to determine the extent of shared vasculature and the degree of vascular contribution by each twin. Just as CTA and CTV are superior for studying vessels, MR imaging is superior for studying the soft-tissue detail of the brain surface. Although the ultrafast sequences, such as single-shot T2-weighted images, have advantages in the constantly moving fetus, more conventional T1, T2, and T1-weighted images after IV gadolinium administration are used in the postnatal imaging. ${ }^{57}$ Volumetric imaging, such as T1-weighted MPRAGE and T2 sampling perfection with applicationoptimized contrasts by using different flip angle evolution (SPACE sequence; Siemens), provide high-resolution anatomic detail with isotropic voxels and can be used in surgical navigation or for modeling. In addition to a standard MR imaging acquisition, high-resolution, heavily T2-weighted volumetric sequences (eg, CISS, FIESTA, and so forth) of the brain surface interface, with a slightly smaller FOV, help evaluate the degree of brain fusion (On-line Fig 3). However, from our experience, even if MR imaging does not clearly show fusion of brain parenchyma, if there is no dural shelf present, fusion may still be present at surgery. In older children or adults, functional MR imaging can be used as a noninvasive way to define hemispheric language dominance and guide surgical planning. Steady-state fMRI could be used in younger children.

\section{Angiography}

DSA can help clarify the arterial and venous anatomy accurately preoperatively. ${ }^{8,20,67}$ Venography is performed by accessing the venous route of the child who has more fully formed sinuses. Balloon occlusion of the communication present between the venous sinuses can then show resulting hemodynamic changes that would result following surgical separation (Fig 9). ${ }^{20,67}$ Embolization of venous structures has also been described to promote the development of collaterals and facilitate an easier surgical venous 


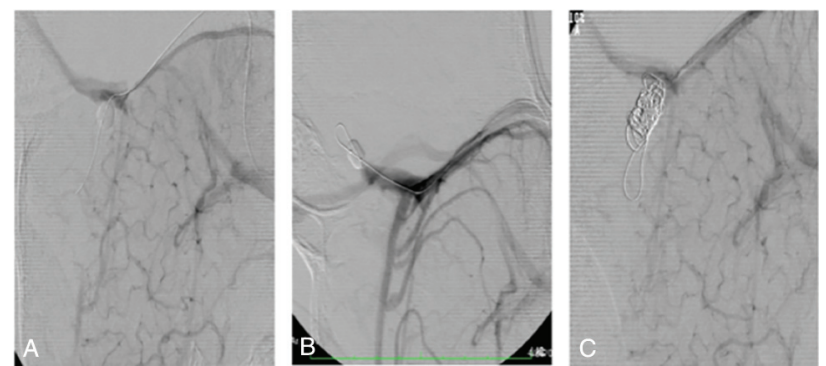

FIG 9. Multiple venous phase left ICA injections show how an occlusion balloon is used to define venous flow between twins ( $A$ and $B$ ). A coil $(C)$ is then placed in a venous sinus to help promote venous collateral formation before surgery.

separation. ${ }^{24,67}$ Coil embolization has also been used in the case of shared arterial supply. ${ }^{42}$

\section{D Models}

Neuroradiologic imaging data have also produced life-sized, 3D, transparent acrylic (On-line Fig 4A) and ceramic (On-line Fig 5) models to better depict surgical anatomy (On-line Fig 6) and holograms depicting the complex intracranial vascular anatomy in relation to the skull and brain. ${ }^{12,15,16,67-69}$ In the operating room, 3D models can be both physically printed for surgical reference or used in conjunction with intraoperative navigation technology. ${ }^{42,69}$ Additionally, 3D modeling can be used to plan the craniotomies, design split-thickness bone grafts (On-line Fig $4 B$ ) to reconstruct cranial defects, and plan scalp tissue expander placement for adequate coverage. ${ }^{67,69}$

\section{Operative Management}

The goal of surgical separation of craniopagus twins involves separating shared structures, including cerebral vasculature and interdigitating brain, and reconstructing cranial structures for each twin. Single and multistage approaches have been used. In the single-stage procedure, the CVS is donated to one twin while reconstructing the sinus in the second twin. In the staged approach, one twin receives the CVS, while the other twin develops a deep venous drainage system during several months by serial ligation of draining veins (On-line Figs 7 and 8). Multistage operations are often not required for partial CPT. Reconstruction includes adequate dural, cranial, and soft-tissue coverage. The dominant twin will have a thriving and more robust clinical presentation, and the nondominant twin may experience the effects of hypotension and low cardiac output, including oliguria, lower weight, aspiration pneumonia, and failure to thrive. Most midline structures, including the CVS, will be donated to the dominant twin, with the plane of division on the side of the nondominant twin (Fig 4).

Despite multiple previous unsuccessful attempts, the first successful separation of CPT occurred in 1953, though only 1 child survived, when a multistaged approach was used. ${ }^{70}$ As techniques improved, single-stage separations became the standard for total CPT separation, in which the surviving twin received the bulk of the superior dural venous sinuses, usually surviving with severe disability, with operations sometimes lasting as long as 22-100 hours. $^{3,7,11-13,15,35,52,53,71}$ Although surgical results for total CPT have been gradually improving across the decades, single-stage results were likely no better than the earlier developed multistaged separation procedures. ${ }^{7}$

Staged surgical separation is the preferred current management of choice in total CPT. ${ }^{46}$ Gradually dividing bridging veins increases collateral formation and dilation of communicating veins in the nondominant twin, who does not receive the superior sagittal sinus. This improves venous drainage, thus reducing the risk of cerebral edema and CSF leak. Additionally, the multistage procedure allows optimal recovery between operations. The cardiac and renal issues and number of medications needed improve by the end of the third stage.

If conjoined brain tissue is present, it should be divided as early as possible to maximize cerebral plasticity. ${ }^{7}$ Surgical separation of TV CPT should ideally be within 9-12 months of age to allow optimal psychomotor development. ${ }^{7}$ Brain fusion of $>30 \%$ bodes a very unsatisfactory outcome with very high morbidity, with a high potential of loss of 1 or both twins.

Adequate dural closure is an extremely important aspect of the operation, with the potential for CSF leakage or meningitis if not done adequately. Methods include autologous, cadaveric, or synthetic dural substitutes and scalp coverage by delayed pedicle flaps or the use of subgaleal tissue expansion. ${ }^{15,25,45,47,69,72}$ Porcine grafts have been used successfully due to their low immune response (On-line Fig 9). CSF shunting after the operation, for hydrocephalus or to promote wound healing, may also be necessary, though the incidence of postoperative hydrocephalus is reduced in the multistage approach. ${ }^{4,12,41}$ In a single case of TA CPT, an external distraction device was used to increase the working distance between the twins after a strip craniectomy was performed to disconnect the fused portions of the skulls. ${ }^{69}$ The efficacy of this additional distraction technique is not clear.

\section{CONCLUSIONS}

Separation of CPT must be a well-orchestrated multidisciplinary effort. The care of these children is extremely resource-intensive, including critical care time, nursing, social support, travel, anesthesia, neurosurgery, diagnostic and interventional neuroradiology, administrative support, and the list continues. The neuroradiologist plays an important role in the care team of CPT, from initial evaluation through the operation and follow-up, using conventional imaging techniques (CT/MR imaging), angiography, and endovascular therapies and creating 3D models. Technologic advances that can greatly improve this field will include 3D virtual reality/augmented reality navigation to improve the knowledge of what lies behind a "wall" of fused brain in the operating theater, keeping loss of brain tissue to a minimum. The combination of high-resolution MR images and virtual reality 3D systems is already in use (12). Embolizing vessels will become even more precise as new endovascular devices and embolic materials become available, decreasing operative time needed for vascular ligation, providing a roadmap for surgeons when they divide veins (liquid embolic materials are clearly seen in superficial vessels with the naked eye), and further mitigating blood loss. With continued innovation, diagnostic and interventional neuroradiology plays an increasingly important role in the care of CPT.

AJNR Am J Neuroradiol 41:951-59 Jun 2020 www.ajnr.org 


\section{REFERENCES}

1. Edmonds LD, Layde PM. Conjoined twins in the United States, 1970-1977. Teratology 1982;25:301-08 CrossRef Medline

2. Spitz L, Kiely EM. Conjoined twins. JAMA 2003;289:1307-10 CrossRef Medline

3. Winston KR, Rockoff MA, Mullikenv JB, et al. Surgical division of craniopagi. Neurosurgery 1987;21:782-91 CrossRef Medline

4. Walker M, Browd SR. Craniopagus twins: embryology, classification, surgical anatomy, and separation. Childs Nerv Syst 2004;20: 554-66 CrossRef Medline

5. Campbell S, Theile R, Stuart G, et al. Craniopagus: second Brisbane case: case report. J Neurosurg 2004;100:519-24 CrossRef Medline

6. Yang Z, Xu G. Craniopagus twins. Chin Med J 2002;115:1262-63 Medline

7. Stone JL, Goodrich JT. The craniopagus malformation: classification and implications for surgical separation. Brain 2006;129(Pt 5):1084-95 CrossRef Medline

8. Nejat F, Habibi Z, Goudarzi M, et al. Emergency separation of craniopagus twins: case report. J Neurosurg Pediatr 2017;20:307-13 CrossRef Medline

9. Hoffman HJ. Craniopagus twins. Neurol Med Chir (Tokyo) 1997; 37:780 Medline

10. Cywes S, Millar AJ, Rode H, et al. Conjoined twins: the Cape Town experience. Pediatr Surg Int 1997;12:234-48 CrossRef Medline

11. Campbell S. Separation of craniopagus twins: the Brisbane experience. Childs Nerv Syst 2004;20:601-06 CrossRef Medline

12. Goh KY. Separation surgery for total vertical craniopagus twins. Childs Nerv Syst 2004;20:567-75 CrossRef Medline

13. Frazee J, Fried I, Kawamoto H, et al. The separation of Guatemalan craniopagus twins. Childs Nerv Syst 2004;20:593-600 CrossRef Medline

14. Khan ZH, Hamidi S, Miri SM. Craniopagus, Laleh and Ladan twins, sagital sinus. Turk Neurosurg 2007;17:27-32 Medline

15. Swift DM, Weprin B, Sklar F, et al. Total vertex craniopagus with crossed venous drainage: case report of successful surgical separation. Childs Nerv Syst 2004;20:607-17 CrossRef Medline

16. Staffenberg DA, Goodrich JT. Separation of craniopagus conjoined twins with a staged approach. J Craniofac Surg 2012;23:2004-10 CrossRef Medline

17. Di Rocco C, Caldarelli M, Tamburrini G, et al. Craniopagus: the Thessaloniki-Rome experience. Childs Nerv Syst 2004;20:576-86 CrossRef Medline

18. Tannuri AC, Batatinha JA, Velhote MC, et al. Conjoined twins: twenty years' experience at a reference center in Brazil. Clinics (Sao Paulo) 2013;68:371-77 CrossRef Medline

19. Ble RK, Seni K, Adjoussou S, et al. Craniopagus conjoined twins: difficulties of management in Africa. Gynecol Obstet Fertil 2008;36: 56-59 Medline

20. Pai KM, Naidu RC, Raja A, et al. Surgical nuances in the separation of craniopagus twins: our experience and a follow-up of $\mathbf{1 5}$ years. Neurol India 2018;66:426-33 CrossRef Medline

21. Browd SR, Goodrich JT, Walker ML. Craniopagus twins. J Neurosurg Pediatr 2008;1:1-20 CrossRef Medline

22. Schindler E, Hajek P. Craniopagus twins: neuroradiological findings (CT, angiography, MRI). Neuroradiology 1988;30:11-16 CrossRef Medline

23. Sudha L, Dev B, Kamble R, et al. Role of biplane digital subtraction angiography, and 3D rotational angiography in craniopagus twins: a case report, detailed pictorial evaluation, and review of literature. J Pediatr Neurosci 2009;4:113-16 CrossRef Medline

24. Alokaili RN, Ahmed ME, Al Feryan A, et al. Neurointerventional participation in craniopagus separation. Interv Neuroradiol 2015; 21:552-57 CrossRef Medline

25. Bucholz RD, Yoon KW, Shively RE. Temporoparietal craniopagus: case report and review of the literature. J Neurosurg 1987;66:72-79 CrossRef Medline
26. Kaufman MH. The embryology of conjoined twins. Childs Nerv Syst 2004;20:508-25 CrossRef Medline

27. Spencer R. Theoretical and analytical embryology of conjoined twins, Part I: embryogenesis. Clin Anat 2000;13:36-53 CrossRef Medline

28. Gaist G, Piazza G, Galassi E, et al. Craniopagus twins: an unsuccessful separation and a clinical review of the entity. Childs Nerv Syst 1987;3:327-33 CrossRef Medline

29. O'Connell JE. Craniopagus twins: surgical anatomy and embryology and their implications. J Neurol Neurosurg Psychiatry 1976;39: 1-22 Medline

30. Spencer R. Conjoined Twins: Developmental Malformations and Clinical Implications. Johns Hopkins University Press; 2003

31. Baldwin M, Dekaban A. Cephalopagus twins seven years after separation: follow-up of a case. J Neurosurg 1965;23:199-203 CrossRef Medline

32. Wolfowitz J, Kerr EM, Levin SE, et al. Separation of craniopagus twins. S Afr Med J 1968;42:412-24 Medline

33. Lansdell $\mathrm{H}$. Intelligence test scores from infancy to adulthood for a craniopagus twin pair neurosurgically separated at 4 months of age. Psychol Rep 1999;84:209-17 CrossRef Medline

34. Stanley P, Anderson FM, Segall HD. Radiologic investigation of craniopagus twins (partial type). AJNR Am J Neuroradiol 1983;4:20608 Medline

35. Sathekge MM, Venkannagari RR, Clauss RP. Scintigraphic evaluation of craniopagus twins. Br J Radiol 1998;71:1096-99 CrossRef Medline

36. Campbell S, Theile R, Stuart G, et al. Separation of craniopagus joined at the occiput: case report. J Neurosurg 2002;97:983-87 CrossRef Medline

37. Voris HC. Cranioplasty in a craniopagus twin. J Neurosurg 1963; 20:145-47 CrossRef Medline

38. Voris HC, Slaughter WB, Christian JR, et al. Successful separation of craniopagus twins. J Neurosurg 1957;14:548-60 CrossRef Medline

39. Marcinski A, Lopatec HU, Wermenski K, et al. Angiographic evaluation of conjoined twins. Pediatr Radiol 1978;6:230-32 CrossRef Medline

40. Konovalov AN, Vaĭchis ChM. The successful separation of a craniopagus (in Russian). Zh Vopr Neirokhir Im N N Burdenko 1991;3-10 Medline

41. O'Connell JE. Surgical separation of two pairs of craniopagus twins. BMJ 1964;1:1333-36 Medline

42. Rutka JT, Souweidane M, ter Brugge K, et al. Separation of craniopagus twins in the era of modern neuroimaging, interventional neuroradiology, and frameless stereotaxy. Childs Nerv Syst 2004;20: 587-92 CrossRef Medline

43. Sonnenburg WM. The blood vascular system in a parietal craniopagus. JAMA 1919;73:1345-48 CrossRef

44. Grossman HJ, Sugar O, Greeley PW, et al. Surgical separation in craniopagus. J Am Med Assoc 1953;153:201-07 CrossRef Medline

45. Winston KR. Craniopagi: anatomical characteristics and classification. Neurosurgery 1987;21:769-81 CrossRef Medline

46. Harvey DJ, Totonchi A, Gosain AK. Separation of craniopagus twins over the past 20 years: a systematic review of the variables that lead to successful separation. Plast Reconstr Surg 2016;138:190200 CrossRef Medline

47. Staffenberg DA, Goodrich JT. Separation of craniopagus conjoined twins: an evolution in thought. Clin Plast Surg 2005;32:25-34, viii CrossRef Medline

48. Wilson H, Storer EH. Surgery in Siamese twins: a report of three sets of conjoined twins treated surgically. Ann Surg 1957;145:71825 CrossRef Medline

49. Lenard HG, Schulte FJ. Polygraphic sleep study in craniopagus twins (where is the sleep transmitter?) J Neurol Neurosurg Psychiatry 1972;35:756-62 CrossRef Medline

50. Villarejo F, Soto M, Amaya C, et al. Total craniopagus twins. Childs Brain 1981;8:149-55 CrossRef Medline 
51. van Ouwerkerk WJ, van den Berg R, Allison CE, et al. Craniopagus: the Suriname-Amsterdam conjunction. Childs Nerv Syst 2004;20: 625-34 CrossRef Medline

52. Huang WQ, Fang JY, Xiao LC, et al. Anesthetic management for separation of craniopagus twins. Acta Anaesthesiol Scand 2004;48: 919-21 CrossRef Medline

53. Cameron DE, Reitz BA, Carson BS, et al. Separation of craniopagus Siamese twins using cardiopulmonary bypass and hypothermic circulatory arrest. J Thorac Cardiovasc Surg 1989;98:961-67 CrossRef Medline

54. Drummond G, Scott P, Mackay D, et al. Separation of the Baragwanath craniopagus twins. Br J Plast Surg 1991;44:49-52 CrossRef Medline

55. Jansen O, Mehrabi VA, Sartor K. Neuroradiological findings in adult cranially conjoined twins: case report. J Neurosurg 1998;89: 635-39 CrossRef Medline

56. O’Neill JA Jr, Holcomb GW 3rd, Schnaufer L, et al. Surgical experience with thirteen conjoined twins. Ann Surg 1988;208:299-312 Medline

57. McHugh K, Kiely EM, Spitz L. Imaging of conjoined twins. Pediatr Radiol 2006;36:899-910, quiz 1002-03 CrossRef Medline

58. Leelanukrom R, Somboonviboon W, Bunburaphong $\mathrm{P}$, et al. Anaesthetic experiences in three sets of conjoined twins in King Chulalongkorn Memorial Hospital. Paediatr Anaesth 2004;14:17683 CrossRef Medline

59. Vagyannavar R, Bhattacharyya A, Misra G, et al. Craniopagus twins for magnetic resonance imaging. Saudi J Anaesth 2017;11:509-10 CrossRef Medline

60. Thomas JM. Anaesthesia for conjoined twins. Childs Nerv Syst 2004;20:538-46 CrossRef Medline
61. Yadav M, Chikkala R, Kulkarni D, et al. Anesthetic management of craniopagus conjoined twins in a remote location. Saudi J Anaesth 2017;11:516-17 CrossRef Medline

62. Dasan TA, N G B, Anvekar SM. A rare case of prenatally detected craniopagus twin. J Clin Diagn Res 2015;9:TJ01-02 CrossRef Medline

63. Sharma UK, Dangol A, Chawla CD, et al. Antenatal detection of conjoined twin. J Nepal Med Assoc 2007;46:133-35 CrossRef Medline

64. Sanhal CY, Ozekinci M, Mendilcioglu I, et al. Prenatal diagnosis of total type 1 vertical craniopagus with 3-dimensional sonography. $J$ Ultrasound Med 2014;33:179-81 CrossRef Medline

65. Rossi AC, Prefumo F. Additional value of fetal magnetic resonance imaging in the prenatal diagnosis of central nervous system anomalies: a systematic review of the literature. Ultrasound Obstet Gynecol 2014;44:388-93 CrossRef Medline

66. Saleem SN. Fetal MRI: an approach to practice-a review. J Adv Res 2014;5:507-23 CrossRef Medline

67. Harvey DJ, Vaca EE, Totonchi A, et al. Eleven-year follow-up of craniopagus twins after unsuccessful attempt at separation: are they better off? Cleft Palate Craniofac J 2019;56:817-22 CrossRef Medline

68. Goodrich JT, Staffenberg DA. Craniopagus twins: clinical and surgical management. Childs Nerv Syst 2004;20:618-24 CrossRef Medline

69. Heuer GG, Madsen PJ, Flanders TM, et al. Separation of craniopagus twins by a multidisciplinary team. N Engl J Med 2019;380:35864 CrossRef Medline

70. Sugar O, Grossman H, Greeley P, et al. The Brodie craniopagus twins. Trans Am Neurol Assoc 1953;3:198-99 Medline

71. Todorov AB, Cohen KL, Spilotro V, et al. Craniopagus twins. J Neurol Neurosurg Psychiatry 1974;37:1291-98 CrossRef Medline

72. Piza-Katzer H. Free allogeneic muscle transfer for cranial reconstruction. Br J Plast Surg 2002;55:436-38 CrossRef Medline 